\title{
Publications of the Geological Survey of Greenland 1994
}

\section{Map}

Precambrian geology between Qarajaq Isfjord and Jakobshavn Isfjord, West Greenland. 1:250 000 compiled by A. A. Garde. 1994.

\section{Bulletins (Bull. Gronlands geol. Unders.)}

169 Palaeontology, stratigraphy and environmental setting of Middle Cambrian outer shelf deposits, North Greenland. 1994 edited by J. S. Peel , 155 pp. (5 articles)

\section{Reports (Rapp. Gronlands geol. Unders.)}

160 Report of Activities 1993, 1994 edited by A. K. Higgins \& M. Sønderholm, $92 \mathrm{pp}$.

161 Current Research. Short scientific papers. 1994. 79 pp. (7 articles)

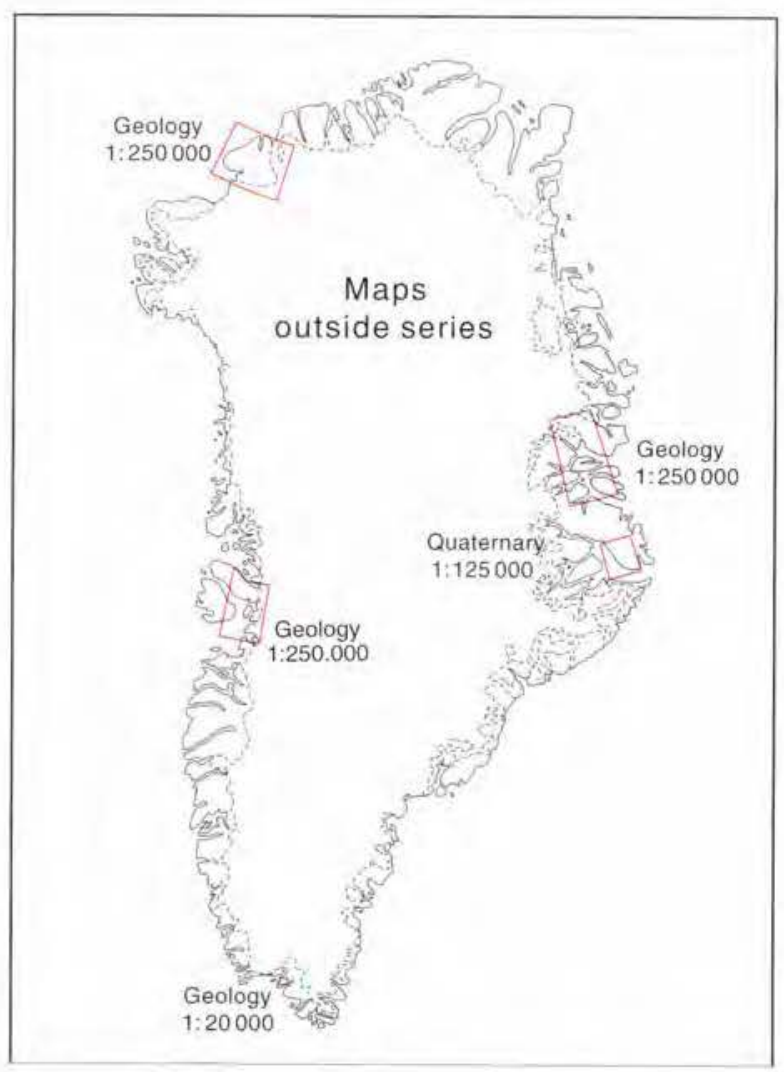

162 Geology of North-East Greenland. 1994 edited by A. K. Higgins, 209 pp. (19 articles)

163 Re-interpretation of Ketilidian geology. 31 pp. ( 2 articles)

164 Current Research. Short scientific papers. 35 pp. (3 articles)

\section{Report of Activities}

Articles in the annual Report of Activities of the Survey published as Rapp. Gronlands geol. Unders. 160.

GGU's aktiviteter i 1993 - nye fund og perspektiver. 1994 by M. Ghisler, 6-7.

Review of the Survey's activities in 1993 - new discoveries and perspectives. 1994 by M. Ghisler, 8-9.

Meeting the role of a modem geological survey: GGU's publication and data service. 1994 by P. R. Dawes, 10-17.

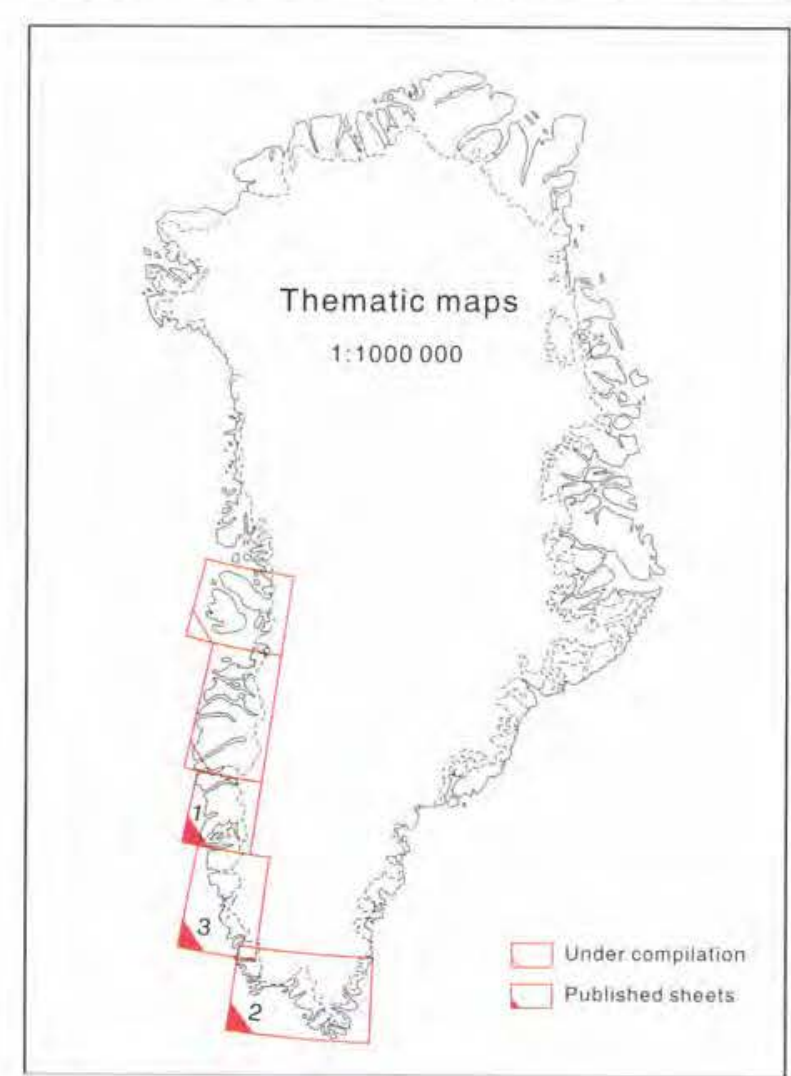


Mineral resource activities 1993: spectrum of research and services. 1994 by H. K. Schønwandt, 18-21.

Themes in the promotion of Greenland's mineral resource potential. 1994 by P. R. Dawes, 22-27.

Project SUPRASYD 1993 - granitic rocks and shear zones with possible gold potential, Julianehåb batholith, South Greenland. 1994 by A. A. Garde \& H. K. Schønwandt, 28-31.

GREENMIN - Database system for the registration of Greenland mineral occurrences. 1994 by M. Lind, T. Tukiainen \& B. Thomassen, 32-36.

Archaean and early Proterozoic basement provinces in Greenland. 1994 by F. Kalsbeek, 37-40.

Large scale geochemical variation in the Precambrian of West and South Greenland. 1994 by A. Steenfelt, 41-44.

Search for meteoritic components in the 3800 million years old Isua supracrustal belt, West Greenland. 1994 by P. W. U. Appel \& M. Chaussidon, 45-46.

Eastern North Greenland 1993-1995 - a new 1:500 000 mapping project. 1994 by N. Henriksen, 47-51.

Petroleum-geological activities in 1993: oil source rocks the dominant theme of the season's field programme. 1994 by F. G. Christiansen \& T. C. R. Pulvertaft, 52-56.

Discovery of live oil at Marraat, Nuussuaq: field work, drilling and logging. 1994 by F. G. Christiansen, G. Dam \& A. K. Pedersen, 57-63.

Sequence stratigraphic studies in the Jameson Land basin, East Greenland. 1994 by S. Piasecki, F. Surlyk, F. Dalhoff, C. F. Hansen, E. B. Koppelhus, N. Noe-Nygaard \& L. Stemmerik, 64-67.

Dinoflagellate cyst stratigraphy of the Barremian to Albian, Lower Cretaceous, North-East Greenland - a summary. 1994 by H. Nøhr-Hansen, 68-72.

ODP activities on the South-East Greenland margin: Leg 152 drilling and continued site surveying. 1994 by H. C. Larsen, A. Saunders, L. M. Larsen, H. Lykke-Andersen, ODP Leg 152 shipboard party, C. Marcussen \& L. Clausen, 73-79.

Greenland glaciers and the 'greenhouse effect', activities 1993. 1994 by R. J. Braithwaite, O. B. Olesen, N. Reeh \& A. Weidick, 80-82.

Glaciological research in Antarctica. 1994 by H. H. Thomsen \& J. O. Hagen, 83-86.

\section{Open File Series}

94/1 Reconnaissance geochemical mapping of the Paamiut region $\left(61^{\circ} 25^{\prime}\right.$ to $62^{\circ} 45^{\prime} \mathrm{N}, 48^{\circ} 00^{\prime}$ to $50^{\circ} 00^{\prime} \mathrm{W}$ ), South-West Greenland. 1994 by A. Steenfelt, E. Dam \& A. Petersen, 16 pp.

94/2 Greenland ornamental stone resources. The 1990/91 ornamental stone project. 1994 by J. Gothenborg, A. A. Garde \& C. Bugnon (P. Erfurt, transl. \& edit.), 143 pp.

94/3 Research and bibliography on the Nagssugtoqidian orogenic belt, West Greenland. 1994 by F. Kalsbeek, 34 pp.
94/4 Industrial mineral occurrences in Greenland - a review. 1994 by P. Kalvig, 94 pp.

94/5 Reconnaissance geochemical mapping of the Maniitsoq region $\left(65^{\circ}\right.$ to $66^{\circ} \mathrm{N}, 51^{\circ} 45^{\prime}$ to $\left.53^{\circ} 30^{\prime} \mathrm{W}\right)$, southern West Greenland. 1994 by A. Steenfelt, A. Petersen \& E. Dam, 15 pp.

94/6 Reconnaissance geochemical mapping of the Aasiaat region $\left(68^{\circ}\right.$ to $68^{\circ} 45^{\prime} \mathrm{N}, 52^{\circ} 45^{\prime}$ to $\left.54^{\circ} \mathrm{W}\right)$, West Greenland. 1994 by A. Steenfelt, A. Petersen \& E. Dam, 10 pp.

94/7 Seeps and other bitumen showings: a review of origin, nomenclature and occurrences in Greenland. 1994 by F. G. Christiansen, 21 pp.

94/8 Organic geochemistry of oil-impregnated cores from the Marraat-1 well, Nuussuaq, West Greenland comparison with surface samples. 1994 by F. G. Christiansen, J. Bojesen-Koefoed \& H. P. Nytoft, $45 \mathrm{pp}$.

94/9 Dinoflagellate cyst biostratigraphy of the Upper Cretaceous black mudstones on Svartenhuk Halvø, West Greenland. 1994 by H. Nøhr-Hansen, 25 pp.

94/10 Shallow core drilling summary sheets: Cretaceous sediments of Nuussuaq and Svartenhuk Halvø (GGU 400701-400712). 1994 by F. G. Christiansen, G. Dam, H. Nøhr-Hansen \& M. Sønderholm, 31 pp.

94/1 1 Well summary Marraat-1 - West Greenland. 1994 by G. Dam \& F. G. Christiansen, 26 pp.

94/12 Dinoflagellate cyst biostratigraphy of the Upper Cretaceous black mudstones in central Nuussuaq, West Greenland. 1994 by H. Nøhr-Hansen, 26 pp.

94/13 Mass balance and related topics of the Greenland ice sheet. Report of the 4th workshop. 1994 edited by J. J. M. van der Meer \& R. J. Braithwaite, $122 \mathrm{pp}$.

94/14 Dinoflagellate cyst biostratigraphy of the Upper Cretaceous black mudstones between Niaqornat and Ikorfat on the north coast of Nuussuaq, West Greenland. 1994 by H. Nøhr-Hansen, 24 pp.

94/15 Field report on palaeo-environmental studies at the Greenland ice sheet margin, Paakitsoq, West Greenland, 1994. 1994 edited by H. H. Thomsen \& N. Reeh, $44 \mathrm{pp}$.

94/16 Dispersion patterns of kimberlite indicator minerals, West Greenland. 1994 by P. W. U. Appel, 37 pp.

94/17 Ore minerals in stream sediments from North Greenland. 1994 by M. Ghisler, 16 pp.

94/19 Reconnaissance geochemical mapping of Lambert Land and southern Kronprins Christian Land ( $79^{\circ}$ to $80^{\circ} 55^{\prime} \mathrm{N}, 18^{\circ} 50^{\prime}$ to $25^{\circ} \mathrm{W}$ ), eastern North Greenland. 1994 by S. M. Jensen, A. Steenfelt \& E. Dam, 19 pp.

\section{Thematic Map Series}

94/1 Regional compilations of geoscience data from the Kap Farvel - Ivittuut area, South Greenland. 1994 edited by L. Thorning, T. Tukiainen \& A. Steenfelt, 27 pp., 71 maps with legends (in 2 volumes). 


\section{Scientific articles}

Refereed works published by GGU or externally. Articles written by non-GGU staff but arising from work partly funded by GGU or from co-operative projects are also included.

Abrahamsen, N. \& Nordgerd, P. 1994: Rock magnetism of Tertiary volcanics from North-East Greenland. Rapp. Grønlands geol. Unders. 162, 195-200.

Appel, P. W. U. 1994: Stratabound scheelite in altered Archaean komatiites, West Greenland. Miner. Deposita 29, 341-352.

Babcock, L. E. 1994: Systematics and phylogenetics of polymeroid trilobites from the Henson Gletscher and Kap Stanton formations (Middle Cambrian), North Greenland. Bull. Grønlands geol. Unders. 169, 79-127.

Babcock, L. E. 1994: Biogeography and biofacies patterns of Middle Cambrian polymeroid trilobites from North Greenland: palaeogeographic and palaeo-oceanographic implications. Bull. Grønlands geol. Unders. 169, 129-147.

Bate, K. J., Whittaker, R. C., Chalmers, J. A. \& Dahl-Jensen, T. 1994: Fylla complex - possible very large gas reserves off S. W. Greenland. Oil Gas J. 92(34), 79-82.

Björklund, A., Lehmuspelto, P., Ottesen, R. T. \& Steenfelt, A. 1994: Drainage geochemistry in glaciated terrain. In Hale, M. \& Plant, J. A. (ed.) Drainage geochemistry. Handbook of exploration geochemistry 6, 307-340,

Braithwaite, R. J. 1994: Thoughts on monitoring the effects of climate change on the surface elevation of the Greenland ice sheet. Global planet. Change 9, 251-261.

Braithwaite, R. J., Laternser, M. \& Pfeffer, W. T. 1994: Variations of near-surface firn density in the lower accumulation area of the Greenland ice sheet, Pâkitsoq, West Greenland. J. Glaciol. 40, 477-485.

Bøggild, C. E., Reeh, N. \& Oerter, H. 1994: Modelling ablation and mass-balance sensitivity to climate change of Storstrømmen, Northeast Greenland. Global Planet. Change 9, 79-90.

Chadwick, B. \& Friend, R. C. L. 1994: Reaction of Precambrian high-grade gneisses to mid-crustal ductile deformation in western Dove Bugt, North-East Greenland. Rapp. Gronlands geol. Unders. 162, 53-70.

Chadwick, B., Erfurt, P., Frisch, T., Frith, R. A., Garde, A. A., Schønwandt, H. K., Stendal, H. \& Thomassen, B. 1994: Sinistral transpression and hydrothermal activity during emplacement of the Early Proterozoic Julianehåb batholith, Ketilidian orogenic belt, South Greenland. Rapp. Gronlands geol. Unders, 163, 5-22.

Chadwick, B., Erfurt, P., Frith, R. A., Nielsen, T. F. D., Schønwandt, H. K. \& Stendal, H. 1994: Re-appraisal of the Ikermit supracrustal suite of the Ketilidian border zone in South-East Greenland. Rapp. Gronlands geol. Unders. 163, 23-31.

Dallmeyer, R. D. \& Strachan, R. A. 1994: ${ }^{40} \mathrm{Ar} /{ }^{39} \mathrm{Ar}$ mineral age constraints on the timing of deformation and metamorphism, North-East Greenland. Rapp. Gronlands geol. Unders. 162, 153-162.
Dallmeyer, R. D., Strachan, R. A. \& Henriksen, N. 1994: ${ }^{40} \mathrm{Ar} /{ }^{39} \mathrm{Ar}$ mineral age record in NE Greenland: implications for tectonic evolution of the North Atlantic Caledonides. J. geol. Soc. Lond. 151, 615-628.

Dam, G. \& Stemmerik, L. 1994: East Greenland lacustrine complexes. In Gierlowski-Kordesch, E. \& Kelts, K. (ed.) Global geological record of lake basins, 19-27. Cambridge University Press.

Dam, G. \& Sønderholm, M. 1994: Lowstand slope channels of the Itilli succession (Maastrichtian - Lower Paleocene), Nuussuaq, West Greenland. Sediment. Geol. 94, 49-71.

Dawes, P. R., Smithies, R. H., Centofanti, J. \& Podmore, D. C. 1994: Unconformable contact relationships between the Muccan and Warrawagine batholiths and the Archaean Gorge Creek Group in the Yarrie mine area, northeast Pilbara. Rec. geol. Surv. Western Australia, 1994/3, 25 pp.

Friderichsen, J. D., Henriksen, N. \& Strachan, R. A. 1994: Basement-cover relationships and regional structure in the Grandjean Fjord - Bessel Fjord region $\left(75^{\circ}-76^{\circ} \mathrm{N}\right)$, North-East Greenland. Rapp. Gronlands geol. Unders. 162, 17-33.

Gilotti, J. A. 1994: Eclogites and related high-pressure rocks from North-East Greenland. Rapp. Grønlands geol. Unders. 162, 77-90.

Hansen, B. T., Henriksen, N. \& Kalsbeek, F. 1994: Age and origin of Caledonian granites in the Grandjean Fjord Bessel Fjord region $\left(75^{\circ}-76^{\circ} \mathrm{N}\right.$ ), North-East Greenland. Rapp. Grønlands geol. Unders. 162, 139-151.

Henriksen, N. 1994: Geology of North-East Greenland $\left(75^{\circ}-78^{\circ} \mathrm{N}\right)$ - the $1988-90$ mapping project. Rapp. Gronlands geol. Unders. 162, 5-16.

Higgins, A. K. (ed.) 1994: Geology of North-East Greenland. Rapp. Gronlands geol. Unders. 162, 209 pp.

Higgins, A. K. \& Soper, N. J. 1994: Structure of the Eleonore Bay Supergroup at Ardencaple Fjord, North-East Greenland. Rapp. Grønlands geol. Unders. 162, 91-101.

Hoelstad, T., Piasecki, S. \& Stemmerik, L. 1994: Shape and size of lacustrine deposited melanogen (opaque organic matter), Upper Carboniferous, East Greenland. Rapp Grønlands geol. Unders. 164, 19-28.

Hull, J. M. \& Gilotti, J. A. 1994: The Germania Land deformation zone and related structures, North-East Greenland. Rapp. Grønlands geol. Unders. 162, 113-127.

Hull, J. M., Friderichsen, J. D., Gilotti, J. A., Henriksen, N., Higgins, A. K. \& Kalsbeek, F. 1994: Gneiss complex of the Skærfjorden region $\left(76^{\circ}-78^{\circ} \mathrm{N}\right)$, North-East Greenland. Rapp. Grønlands geol. Unders. 162, 35-51.

Ineson, J. R., Surlyk, F., Higgins, A. K. \& Peel, J. S. 1994: Slope apron and deep shelf sediments of the Brønlund Fjord and Tavsens Iskappe Groups (Lower Cambrian Lower Ordovician), North Greenland: stratigraphy, facies and depositional setting. Bull. Grønlands geol. Unders. 169, 7-24.

Jensen, S. M. 1994: Lead isotope signatures of mineralised rocks in the Caledonian fold belt of North-East Greenland. Rapp. Grønlands geol. Unders. 162, 169-176. 
Jensen, S. M. \& Stendal, H. 1994: Reconnaissance for mineral occurrences in North-East Greenland. Rapp. Grønlands geol. Unders. 162, 163-168.

Jensen, Aa. \& Nielsen, T. F. D. 1994: Blue cancrinite from South-East Greenland. Rapp. Grønlands geol. Unders. $161,5-10$.

Jepsen, A.-M., Thomsen, R. O., Christiansen, F. G., Surlyk, F. \& Lerche, I. 1994: On the use of equivalent vitrinite reflectance from the Lower Palaeozoic of North Greenland to estimate erosion event parameters. Nucl. Geophys. 8, 473-483.

Jepsen, H. F., Escher, J. C., Friderichsen, J. D. \& Higgins, A. K. 1994: The geology of the north-eastern corner of Greenland - photogeological studies and 1993 field work. Rapp. Grønlands geol. Unders. 161, 21-33.

Kalvig, P. \& Appel, P. W. U. 1994: Greenlandic mineral resources for use in advanced materials. Industrial Minerals 319, 45-51.

Krabbe, H., Christiansen, F. G., Dam, G., Piasecki, S. \& Stemmerik, L. 1994: Organic geochemistry of the Lower Jurassic Sortehat Formation, Jameson Land, East Greenland. Rapp. Grønlands geol. Unders. 164, 5-18.

Landvik, J. Y. 1994: The last glaciation of Germania Land and adjacent areas, northeast Greenland. J. Quat. Res. 9, 81-92.

Larsen, H. C., Saunders, A.D., Clift, P. \& ODP Leg 152 Party 1994: Initial Report, ODP Leg 152. College Station: Texas A \& M University, $977 \mathrm{pp}$.

Nielsen, T. F. D. 1994: Alkaline dike swarms of the Gardiner complex and the origin of ultramafic alkaline complexes. Geochem. int. 31(3), 37-56. [translation of: Geokhemya 1993(8), 1112-1131]

Nilsson, I. 1994: Upper Palaeozoic fusulinid assemblages, Wandel Sea Basin, North Greenland. Rapp. Grønlands geol. Unders. 161, 45-71.

Nutman, A. P. \& Kalsbeek, F. 1994: Search for Archaean basement in the Caledonian fold belt of North-East Greenland. Rapp. Gronlands geol. Unders. 162, 129-133.

Nutman, A. P. \& Kalsbeek, F. 1994: A minimum age of 2944 $\pm 7 \mathrm{Ma}$ for the Tartoq Group, South-West Greenland. Rapp. Grønlands geol. Unders. 161, 35-38.

Peel, J. S. 1994: An enigmatic cap-shaped fossil from the Middle Cambrian of North Greenland. Bull. Gronlands geol. Unders. 169, 149-155.

Piasecki, S., Stemmerik, L., Friderichsen, J. D. \& Higgins, A. K. 1994: Stratigraphy of the post-Caledonian sediments in the Germania Land area, North-East Greenland. Rapp. Grønlands geol. Unders. 162, 177-184.

Reeh, N., Bøggild, C. E. \& Oerter, H. 1994: Surge of Storstrømmen, a large outlet glacier from the Inland Ice of North-East Greenland. Rapp. Grønlands geol. Unders. 162, 201-209.
Robison, R. A. 1994: Agnostoid trilobites from the Henson Gletscher and Kap Stanton formations (Middle Cambrian), North Greenland. Bull. Gronlands geol. Unders. 169, 25-77.

Shearer, C. K. \& Larsen, L. M. 1994: Sector-zoned aegirine from the Ilímaussaq alkaline intrusion, South Greenland: implications for trace-element behavior in pyroxene. Amer. Miner. 79, 340-352.

Springer, N. \& Friderichsen, J. D. 1994: Age of low-grade regional metamorphism in the North Greenland fold belt: mineralogical and $\mathrm{Rb}$-Sr-isotope evidence from pelitic metasediments. Can. J. Earth Sci. 31, 358-368.

Stecher, O. \& Henriksen, N. 1994: Sm-Nd model age of an early Proterozoic gabbro-anorthosite from the Caledonian fold belt in North-East Greenland. Rapp. Grønlands geol. Unders. 162, 135-137.

Steenfelt, A. 1994: Crustal structure in West and South Greenland reflected by regional distribution patterns of calcium and potassium in stream sediments. Rapp. Grønlands geol. Unders. 161, 11-20.

Stemmerik, L. \& Elvebakk, G. 1994: A newly discovered mid-Carboniferous - ?early Permian reef complex in the Wandel Sea Basin, eastern North Greenland. Rapp. Grønlands geol. Unders. 161, 39-44.

Stemmerik, L., Larson, P. A., Larssen, G. B., Mørk, A. \& Simonsen, B. T. 1994: Depositional evolution of Lower Permian Palaeoaplysina build-ups, Kapp Duner, Formation, Bjørnøya, Arctic Norway. Sediment. Geol. 92, 161-174.

Strachan, R. A. 1994: Evidence in North-East Greenland for Late Silurian - Early Devonian regional extension during the Caledonian orogeny. Geology 22, 913-916.

Strachan, R. A. \& Tribe, I. R. 1994: Structure of the Storstrommen shear zone, eastern Hertugen af Orléans Land, NorthEast Greenland. Rapp. Grønlands geol. Unders. 162, 103-112,

Strachan, R. A., Friderichsen, J. D., Holdsworth, R. E. \& Jepsen, H. F. 1994: Regional geology and Caledonian structure, Dronning Louise Land, North-East Greenland. Rapp. Grønlands geol. Unders. 162, 71-76.

Thomas, A. T. 1994: Silurian trilobites from the G. D. Schley Fjord region, eastern Peary Land, North Greenland. Rapp. Gronlands geol. Unders. 164, 29-35.

Weidick, A. 1994: Historical fluctuations of calving glaciers in South and West Greenland. Rapp. Gronlands geol. Unders. 161, 73-79.

Watt, W.S. 1994: Stratigraphy and correlation of the Tertiary plateau basalts in North-East Greenland. Rapp. Grønlands geol. Unders. 162, 185-194. 